\title{
Problem Analysis on Teachers in the Development of Discovery Learning Model- based Worksheet and Student Problem on Cognitive Learning Achievement
}

\section{Analisis Permasalahan Guru Terkait Pengembangan LKS Berbasis Model Discovery Learning dan Permasalahan Siswa Terkait Hasil Belajar Kognitif}

\author{
Panca Herlambang, Evi Palenewen, Susilo \\ Email: abi lambang@yahoo.com \\ Pendidikan Biologi-Fakultas Keguruan dan Ilmu Pendidikan \\ Universitas Mulawarman Jl. Gunung Kelua samarinda.
}

\begin{abstract}
The purpose of this research is to analyze the development of Biology worksheet about Blood Circulation System based on Discovery Learning model in SMA Negeri Samarinda. The research targets are (1) to describe the teacher's level of understanding about Discovery Learning model-based worksheet (2) to find solutions to solve teacher problem about worksheet development (3) to find out the level of student achievement (4) to find solutions regarding to low students' learning achievement. The participants of this research are Biology teachers at SMAN 6, SMAN 14, SMAN 4 and SMAN 3 Samarinda. The results of this study were analyzed using qualitative descriptive methods. The results of this study indicate that (1) The teachers' understanding about the development of Discovery Learning-based Biology worksheet is still inadequate so that worksheet application was not optimal in teaching and learning process. (2) The teachers still experience some difficulties in synthesising worksheet, thus teachers need more explanations and references in the development of Discovery Learning model-based worksheet. (3) The students' learning achievement are not optimal, (4) Teachers' guidance is the best solution to improve the students' achievement.
\end{abstract}

Key Words: Problem analysis, Worksheet, Discovery Learning, students' achievement

\begin{abstract}
Abstrak : Penelitian ini bertujuan untuk melakukan analisis kebutuhan pengembangan LKS biologi pada materi sistem peredaran darah berbasis model Discovery Learning di SMA Negeri Samarinda. Target penelitian adalah untuk memperoleh (1) gambaran tingkat pemahaman guru terkait LKS berbasis model Discovery Learning (2) Solusi dalam mengatasi permasalahan guru terkait pengembangan LKS (3) tingkat pencapaian hasil belajar siswa .(4) solusi dalam mengatasi hasil belajar siswa. Populasi penelitian analisis kebutuhan ini adalah guru Biologi pada SMAN 6 ,SMAN 14, SMAN 4 , dan SMAN 3 Samarinda. Hasil observasi permasalahan guru dan siswa yang di analisis secara deskriptif kualitatif menunjukkan bahwa (1) Pemahaman guru terkait pengembangan LKS biologi berbasis model Discovery Learning masih kurang sehingga penerapannya dalam kegiatan belajar mengajar tidak optimal. (2) Guru mengalami kendala dalam pembuatan LKS oleh karena itu guru memerlukan sosialisasi dan acuan referensi dalam pengembangan LKS berbasis model Discovery Learning dan (3) Hasil belajar siswa masuk kategori kurang, (4) Rendahnya hasil belajar siswa perlu diatasi dengan bimbingan dan pendampingan yang penuh oleh guru terkait hasil belajar siswa.
\end{abstract}

Kata kunci : Analisis permasalahan , LKS, Discovery Learning, hasil belajar. 


\section{PENDAHULUAN}

Pendidikan adalah salah satu bentuk perwujudan kebudayaan manusia yang dinamis dan syarat perkembangan kebudayaan. Oleh karena itu perubahan atau perkembangan pendidikan adalah hal yang memang seharusnya terjadi sejalan dengan perubahan budaya kehidupan. Perubahan dalam arti perbaikan pendidikan pada semua tingkat perlu terus menerus dilakukan sebagai antisipasi masa depan dan tuntutan masyarakat modern (Sofian, 2013). Pendidikan merupakan salah satu usaha untuk mewujudkan masyarakat yang berkualitas. Oleh karena itu pemerintah Indonesia selalu berusaha untuk meningkatkan kualitas pendidikan seperti yang tercantum dalam pembukaan Undang-Undang Dasar 1945 alenia keempat yang berbunyi mencerdaskan kehidupan bangsa. Pendidikan adalah usaha sadar dan terencana untuk mewujudkan suasana belajar dan proses belajar agar peserta didik secara aktif mengembangkan potensi dirinya untuk memiliki kekuatan spiritual keagamaan, pengendalian diri, kepribadian, kecerdasan, akhlak mulia, serta ketrampilan yang diperlukan dirinya, masyarakat, bangsa dan Negara. Salah satu penentu kualitas pendidikan di sekolah adalah profesionalisme seorang guru (Asmara J, 2016).

Untuk mewujudkan tujuan pendidikan tersebut diperlukan peningkatan kualitas sumber daya manusia yang berkecimpung dalam bidang pendidikan yaitu guru sebagai ujung tombak pelaksanaan pendidikan di sekolah. Guru harus memiliki kompetensi pdagogik yang diperlukan untuk pengajaran (Sadikin, A, 2017). Guru yang profesional adalah guru yang selalu mengevaluasi hasil mengajarnya. Begitu pula dengan perangkat pembelajaran. Guru dapat mengevaluasi dirinya sendiri sejauh mana perangkat pembelajaran yang telah dirancang teraplikasi di dalam kelas. Evaluasi tersebut penting untuk terus meningkatkan profesionalime seorang guru. Kegiatan evaluasi bisa dimulai dengan membandingkan dari berbagai aktivitas di kelas, strategi, metode atau bahkan langkah pembelajaran dengan data yang ada di perangkat pembelajaran.

Seorang guru yang profesional harus memiliki kemampuan dan ketrampilan untuk menyusun dan mengembangkan perangkat pembelajaran yang akan digunakan dalam kegiatan pembelajaran di kelas. Perangkat pembelajaran yang dikembangkan harus disesuaikan dengan kurikulum yang Siswa digunakan dan di sesuaikan dengan kebutuhan siswa di dalam kelas salah satunya adalah Lembar Kerja Siswa (LKS). Aktivitas di dalam kelas sangat di tunjang dengan Lembar Kerja Siswa yang dipersiapkan oleh guru.Lembar Kerja (LKS) inilah yang akan digunakan guru sebagai pedoman dalam kegiatan pembelajaran sehingga pembelajaran akan berlangsung secara terarah sesuai dengan tujuan pembelajaran dan indikator yang harus dicapai sehingga di harapkan umpan balik berupa hasil belajar siswa yang optimal.

Lembar Kerja Siswa (LKS) digunakan sebagai sarana untuk mengoptimalkan hasil belajar peserta didik dan meningkatkan keterlibatan peserta didik dalam proses belajar-mengajar. LKS adalah lembaran yang berisi tugas yang harus dikerjakan oleh siswa. Tugas yang diperintahkan dalam LKS harus mengacu pada kompetensi dasar yang akan dicapai oleh siswa. Tugas tersebut 
bisa berupa tugas teoritis dan tugas praktis ( Depdiknas,2007). Secara umum LKS merupakan perangkat pembelajaran sebagai pelengkap atau sarana pendukung pelaksanaan Rencana Pelaksanaan Pembelajaran (RPP). LKS ini sangat baik digunakan untuk meningkatkan keterlibatan peserta didik dalam belajar baik dipergunakan dalam penerapan metode terbimbing maupun untuk memberikan latihan pengembangan.

Bukti di lapangan menunjukan fakta yang tidak sesuai harapan, dimana Guru tidak mengembangkan Lembar Kerja Siswa (LKS) yang dimiliki hal ini terbukti dari temuan dilapangan bahwa dokumen perangkat pembelajaran khususnya Lembar Kerja Siswa (LKS) yang di miliki guru menggunakan LKS dari penerbit ketika di cross cek di bagian kurikulum. Berkaitan dengan pengembangan Lembar Kerja Siswa ini perlu kita analisis permasalahan guru sebagai ujung tombak pendidikan dalam menyusun lembar kerja siswa (LKS) biologi yang digunakan, Guru harus mengenali kebutuhan siswa di kelas yang disesuaikan dengan kondisi sekolah dan karakteristik siswa sehingga guru akan lebih optimal dalam menyusun Lembar Kerja Siswa (LKS) biologi sesuai kebutuhan siswa (Dewi. R, Budiarti. R.S, dan Aina. M. (2017).

Fakta yang ditemukan disekolah-sekolah ternyata guru masih menggunakan cara mengajar konvesional yakni pembelajaran yang berpusat pada guru walaupun disekolah sudah menerapkan Kurikulum 2013 yang menuntut pembelajaran berpusat pada siswa, dengan alasan untuk mencapai target kurikulum karena waktu di jam tatap muka di kelas tidak mencukupi karena digunakan untuk kegiatan sekolah. Sehingga siswa cenderung pasif dan hanya mendengarkan penjelasan guru , karena guru rata-rata memilih metode ceramah yang dianggap praktis dan tidak perlu untuk menyiapkan perangkat pembelajaran khususnya Lembar Kerja Siswa (LKS) sesuai kebutuhan siswa. Padahal pada kurikulum 2013 siswa dituntut untuk aktif, kreatif, mandiri, bertanggung jawab sehingga menjadi pribadi yang cakap dan trampil dan peran guru di dalam kegiatan pembelajaran sebagai fasilitator siswa yang membimbing dan mengarahkan serta memfasilitasi kegiatan pembelajaran yang berlangsung. Hal inilah yang memicu hasil belajar siswa yang tidak optimal sehingga diperlukan solusi untuk mengatasi permasalahan tersebut. Padahal Penerapan Assesment yang tepat akan dapat meningkatkan kemampuan metakognitif dan hasil belajar siswa (Sadikin. A, 2016).

Pembelajaran Biologi seharusnya lebih menekankan pada kegiatan yang melatih kemampuan berpikir ilmiah siswa melalui kegiatan-kegitan percobaan baik eksperimen maupun demonstrasi. Diharapkan dengan kegiatan-kegiatan pembelajaran tersebut, siswa tidak hanya sekedar memahami konsep dan prinsip keilmuan saja tetapi juga memiliki kemampuan dalam berbuat menggunakan konsep dan prinsip keilmuan yang diperolehnya. Untuk mewujudkan pembelajaran seperti itu pendekatan discovery merupakan salah satu yang dapat diterapkan pada pembelajaran biologi karena discovery lebih menekankan kepada penemuan konsep atau materi pembelajaran oleh siswa sendiri, bukan mendengarkan ceramah dari guru saja 
Jika di kaji secara mendalam masalah-masalah diatas berkaitan dengan penyusunan perangkat pembelajaran yang ada di sekolah yakni Lembar Kerja Siswa (LKS) yang akan di jadikan pedoman dan penunjang kelancaran dalam pelaksanaan proses pembelajaran dan kegiatan pelaksanaan perangkat pembelajaran yang sudah di rencanakan dalam pembelajaran dikelas . Seorang guru yang memahami betul penyusunan LKS sebagai salah satu perangkat pembelajaran dan merencanakan dengan baik maka pelaksanaan proses pembelajaran di kelas akan terarah dan lancar sesuai yang diharapkan yaitu mampu mencapai tujuan pembelajaran sehingga bisa meningkatkan hasil belajar kognitif siswa yang optimal. Berdasarkan latar belakang masalah diatas maka penelitian ini ,perlu dilakukan analisis yang mendalam sebagai kajian awal dalam pengembangan Lembar Kerja Siswa Biologi pada materi sistem peredaran darah berbasis model pembelajaran Discovery Learning untuk meningkatkan hasil belajar siswa. Selain itu penelitian ini bertujuan untuk mengetahui tingkat pemahaman guru biologi SMA terkait penyusunan Lembar Kerja Siswa Biologi melalui model Discovery Learning dan rumusan solusi dalam mengatasi permasalahan guru terkait pengembangan Lembar Kerja Siswa (LKS) biologi di SMA.

\section{METODE}

Kegiatan utama penelitian ini adalah analisis kebutuhan dalam pengembangan Lembar Kerja Siswa (LKS) dan hasil belajar siswa pada materi sistem peredaran darah dengan model pembelajaran Discovery Learning. Metode yang digunakan dalam penelitian adalah metode survei dengan kuisioner dan pedoman wawancara tidak terstruktur kepada beberapa guru mata pelajaran

Biologi di SMA. Para guru akan mengisi kuisioner yang dirancang oleh peneliti berdasarkan indikator penilaian dalam penelitian ini untuk mengetahui tingkat kegiatan guru terkait pengembangan Lembar Kerja Siswa (LKS) dalam kegiatan belajar mengajar oleh guru dan tingkat pencapaian hasil belajar siswa serta tanggapan guru terkait pengembangan Lembar Kerja Siswa (LKS) yang dilakukan penulis. Penelitian ini akan menganalisis dan mengidentifikasi permasalahan guru dan siswa sehingga diperoleh diskripsi kegiatan guru terkait pengembangan Lembar Kerja Siswa (LKS) dan deskripsi hasil belajar siswa di SMAN Samarinda kelas XI. Lokasi penelitian ini di SMAN 6, SMAN 14, SMAN 4 dan SMAN 3 Samarinda dan berlangsung selama 3 bulan dari bulan September - Nopember 2017.

\subsection{Teknik Analisis Data}

Teknik analisis data yang digunakan dalam penelitian ini adalah persentase berdasarkan hasil jawaban dari angket yang disebarkan pada sampel dan hasil wawancara tak terstruktur pada sampel. Data yang diperoleh akan dianalisis secara deskriptif. 


\subsection{Subjek dan Objek Penelitian}

Subjek penelitian adalah guru Biologi SMAN 6, SMAN 4, SMAN 14, dan SMAN 3 Samarinda. Para guru ini akan mengisi kuesioner yang telah dirancang oleh peneliti berdasarkan indikator penilaian dalam penelitian ini guna mengetahui kelayakan Lembar Kerja Siswa (LKS) yang digunakan oleh guru serta tanggapan guru terkait pengembangan Lembar Kerja Siswa (LKS) berbasis model Discovery Learning yang akan dilakukan penulis.

\section{HASIL DAN PEMBAHASAN}

Berdasarkan hasil penelitian survey yang dilaksanakan peneliti di SMA Negeri 6, SMA Negeri 4, SMA Negeri 14, dan SMA Negeri 3 Samarinda di kelas XI di peroleh hasil sebagai berikut : secara garis besar akar permasalahan bisa dikelompokkan menjadi dua yaitu permasalahan guru dan permasalahan siswa .Permasalahan guru terjadi karena (1)rendahnya pemahaman guru mengenai Lembar Kerja Siswa (LKS) (2)kurangnya referensi dan buku acuan guru, (3)rendahnya motivasi guru untuk mengembangkan Lembar Kerja Siswa(LKS), (4) kendala waktu yang membuat guru enggan menggunakan berbagai model pembelajaran (5) Kreatifitas dan inovasi guru yang rendah (6)sarana yang tidak mendukung. Sedangkan akar permasalahan siswa yakni (1)kurangnya perhatian siswa dalam pembelajaran, (2)kurangya keaktifan siswa dalam pembelajaran, (3)rendahnya hasil belajar kognitif siswa dalam pembelajaran.

Lembar Kerja Siswa adalah panduan siswa yang digunakan untuk melakukan kegiatan penyelidikan atau pemecahan masalah. Lembar kegiatan ini dapat berupa panduan untuk latihan pengembangan aspek kognitif maupun panduan untuk pengembangan semua aspek pembelajaran dalam bentuk panduan eksperimen atau demonstrasi (Trianto, 2007) .

LKS berwujud lembaran-lembaran berisi tugas-tugas guru kepada siswa yang disesuaikan dengan kompetensi dasar dan tujuan pembelajaran yang ingin dicapai. LKS dapat mempermudah guru dan siswa dalam pelaksanaan kegiatan pembelajaran. Hal tersebut penting karena proses pembelajaran adalah sesuatu yang sistematis dan terpola. Dewasa ini masih banyak guru yang menggunakan LKS yang disediakan oleh penerbit sehingga siswa kesulitan mengikuti kegiatan pembelajaran karena LKS yang digunakan tidak sesuai dengan kebutuhan siswa.

Dari hasil observasi secara umum didapatkan fakta yang menunjukkan bahwa pengembangan perangkat pembelajaran berupa Lembar Kerja Siswa (LKS) oleh guru belum optimal pemanfaatannya, yakni sangat rendah padahal materi biologi perlu didukung oleh Lembar Kerja Siswa yang memadai. Guru menemui kesulitan dalam penyusunan Lembar Kerja Siswa (LKS ). Hal ini bisa di lihat pada gambar 1. berupa grafik pemahaman guru terkait pengembangan Lembar Kerja Siswa (LKS) dengan model Discovery Learning berdasarkan rekapitulasi hasil perolehan angket kuisioner survei berikut ini : 


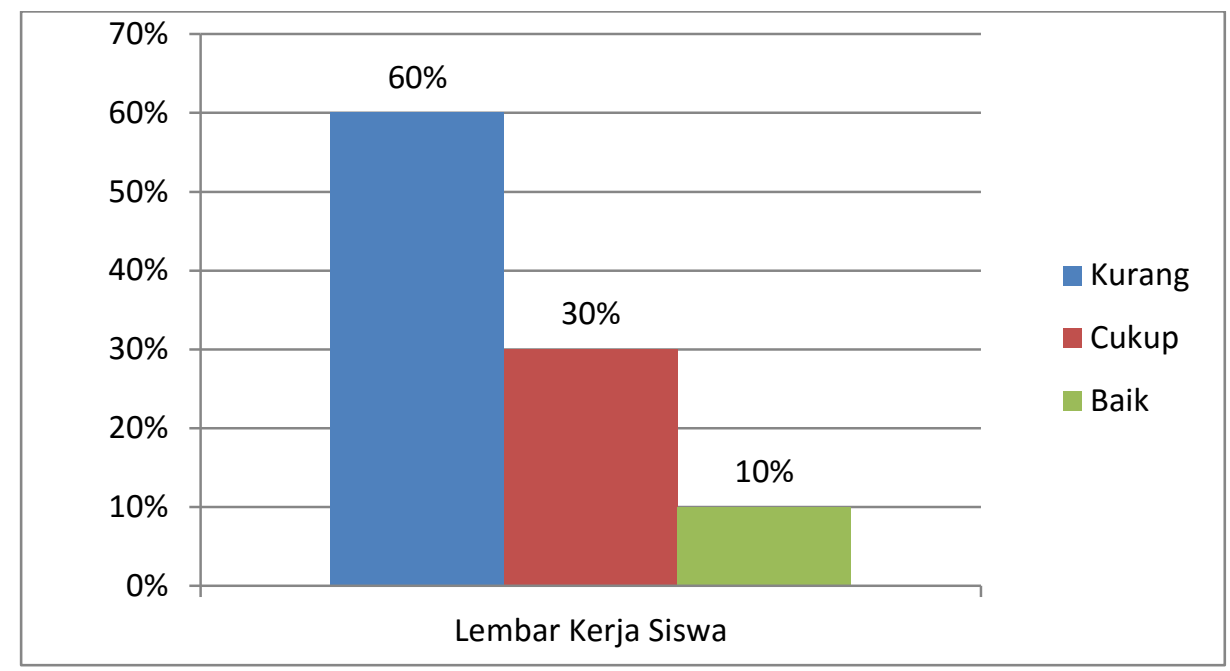

Gambar 1. Grafik Pemahaman Guru Terkait Lembar Kerja Siswa

Berdasarkan data pada gambar I, yakni grafik pemahaman guru terkait Lembar Kerja Siswa (LKS) dengan model Discovery Learning bisa kita analisis bahwa pemahaman guru terkait Lembar Kerja Siswa termasuk kategori kurang yakni 60\%. Hanya $10 \%$ guru yang masuk kategori baik tingkat pemahamannya. Upaya yang masih kurang optimal dilakukan oleh guru dalam penggunaan Lembar Kerja Siswa dalam kegiatan belajar mengajar tidak sesuai dengan tuntutan kurikulum yang diterapkan padahal materi biologi perlu didukung oleh Lembar Kerja Siswa (LKS) yang matang. Permasalahan ini terjadi karena kurangnya referensi dan motivasi guru untuk merencanakan dan mempersiapkan Lembar Kerja Siswa (LKS) yang akan digunakan, hal ini menggambarkan pengetahuan guru terkait pemahaman Lembar Kerja Siswa (LKS) masih rendah . Sehingga guru perlu diberi bimbingan dan pembinaan untuk meningkatkan pemahaman dan pengetahuan tentang penyusunan Lembar Kerja Siswa (LKS) dan menyadari pentingnya pengembangan Lembar Kerja Siswa (LKS) yang disesuaikan dengan kebutuhan siswa yang akan digunakan untuk menunjang keberhasilan proses pembelajaran. Pentingnya kegiatan perencanaan dan persiapan perangkat pembelajaran juga tertuang dalam Permendikbud No.65 Tahun 2013 tentang Standar Proses Pendidikan Dasar dan Menengah disebutkan bahwa penyusunan perangkat pembelajaran merupakan bagian dari perencanaan pembelajaran. Lembar Kerja Siswa (LKS) merupakan salah satu perangkat pembelajaran yang sangat menentukan arah kegiatan belajar mengajar di kelas agar tidak lepas dari tujuan pembelajaran.

Dari hasil penelitian dilapangan diketahui bahwa kegiatan pelaksanaan proses belajar mengajar di dalam kelas tidak seperti yang di harapkan. Dimana pembelajaran masih berpusat pada guru karena kegiatan belajar mengajar oleh guru masih dominan menggunakan metode ceramah yang dianggap lebih praktis untuk mengatasi berbagai kendala dalam pelaksanaan pembelajaran. 


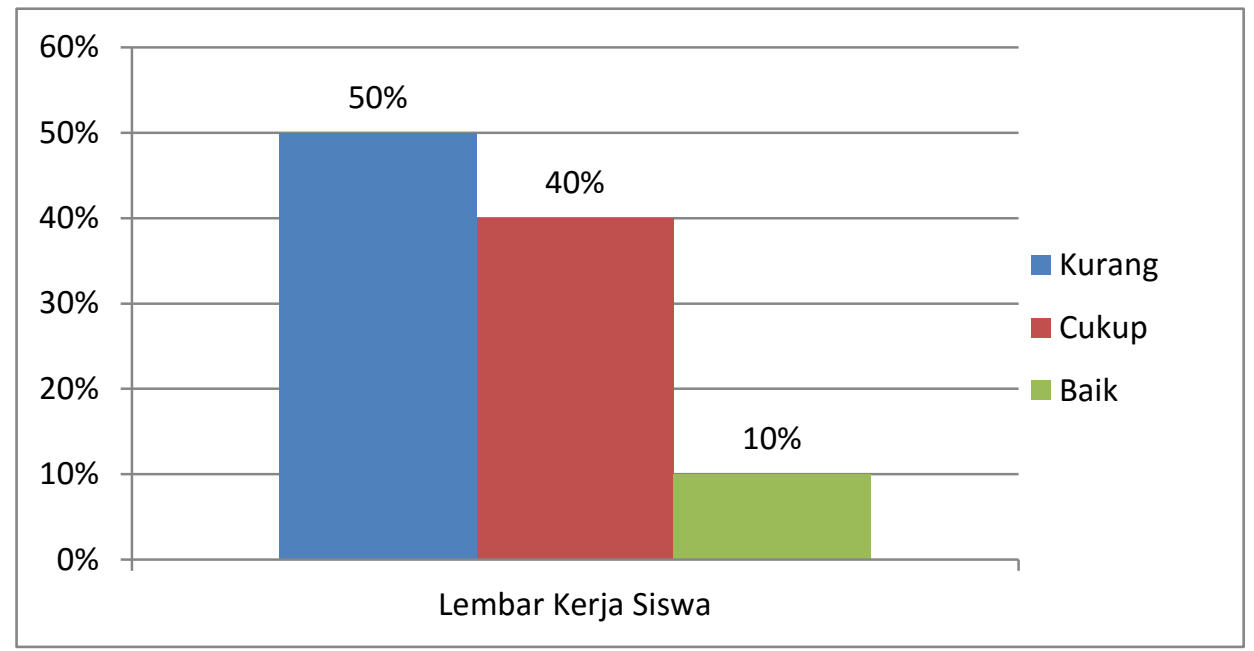

Gambar 2. Grafik Kegiatan Pelaksanaan Guru terkait Lembar Kerja Siswa

Gambar 2. terfokus pada kegiatan pelaksanaan pembelajaran guru terkait Lembar Kerja siswa dengan model Discovery Learning yang menunjukkan bahwa tingkat pelaksanaanan pembelajaran guru terkait Lembar Kerja Siswa (LKS) masuk kategori kurang yakni $50 \%$. Permasalahan kegiatan pelaksanaan pembelajaran guru terkait Lembar Kerja Siswa (LKS) yang masih kurang ini bisa disebabkan oleh berbagai kendala di lapangan yakni keterbatasan waktu, kurangnya referensi guru dalam pembelajaran, jumlah rombel yang banyak dalam satu kelas dan sarana yang tidak memadai sehingga guru memilih melaksanakan pembelajaran dengan cara yang instan dan mudah diterapkan dan dianggap bisa menyelesaikan berbagai kendala tersebut dengan menggunakan model pembelajaran berpusat pada guru dan menggunakan Lembar Kerja Siswa (LKS) yang disediakan oleh penerbit yang tidak sesuai dengan kebutuhan siswa. Kurangnya kegiatan pelaksanaan guru terkait LKS ini tentunya akan berpengaruh pada hasil belajar siswa , karena tanpa penggunaan LKS yang disesuaikan dengan kondisi siswa maka kegiatan pembelajaran menjadi tidak terarah dan tujuan pembelajaran tidak akan tercapai sehingga proses pembelajaran dikelas tidak efektif. Solusi untuk mengatasi hal itu adalah dengan memberikan bimbingan dan pendampingan guru melalui berbagai upaya salah satunya melalui MGMP dan pelatihan sehingga guru bisa lebih kreatif dan inovatif dalam pengembangan LKS yang menunjang kegiatan pelaksanaan pembelajaran di kelas. Berdasarkan hasil wawancara tak terstruktur antara peneliti dengan guru dijelaskan bahwa hasil belajar kognitif siswa pada materi sistem peredaran darah masih kurang optimal,hal ini bisa dilihat dari data yang diperoleh dilapangan. 


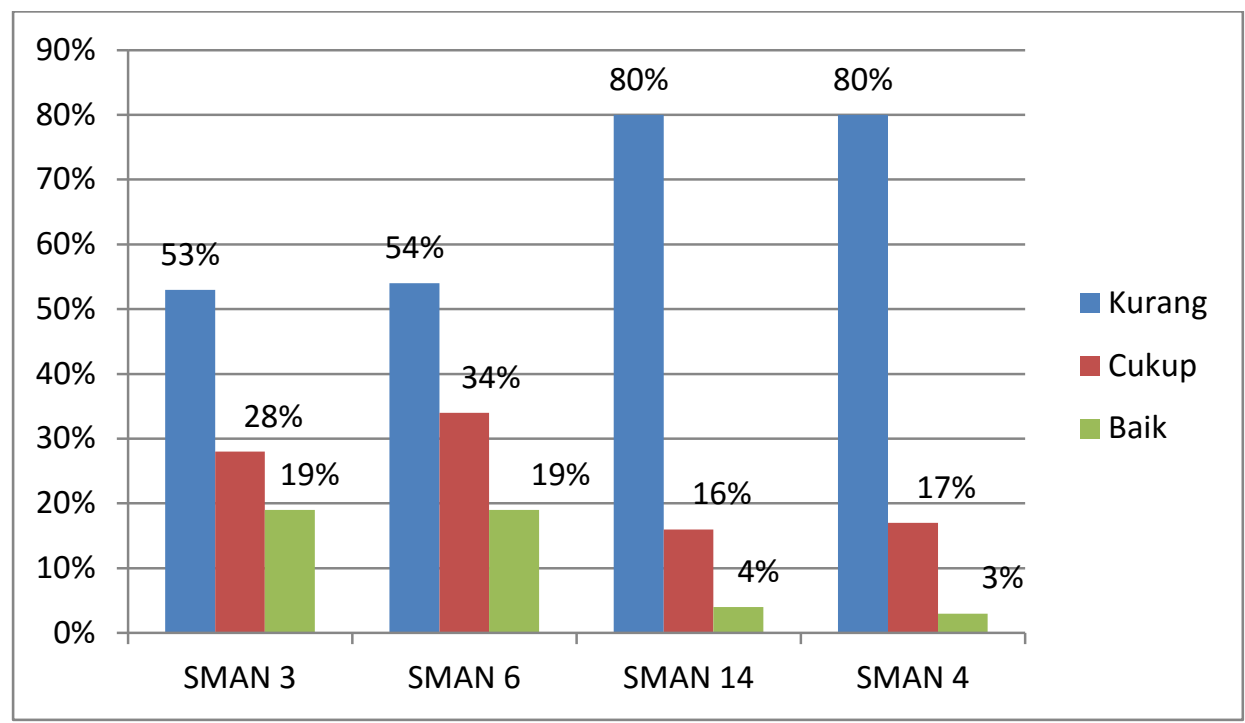

Gambar 3. Grafik Rekapitulasi Hasil Belajar Siswa Terkait Terkait Materi Sistem Peredaran Darah.

Analisis mengenai rekapitulasi hasil belajar siswa terkait materi sistem peredaran darah dapat kita amati pada gambar 3, berupa grafik hasil belajar kognitif siswa terkait materi sistem gerak kelas XI di keempat sekolah masuk kategori kurang dengan persentasi di SMAN 3 samarinda kategori kurang 53\%, SMAN 6 Samarinda kategori kurang 54\%, SMAN 14 Samarinda kategori kurang $80 \%$, SMAN 4 Samarinda kategori kurang $80 \%$.

Dari hasil observasi di lapangan guru mengeluhkan kurangnya motivasi belajar siswa di kelas,hal ini tertuang dalam pernyataan guru yang mengatakan banyak siswa yang pasif di kelas dan menunjukkan sikap kurang perhatian dengan pembelajaran yang berlangsung, sehingga hasil belajar kognitif siswa rendah.Padahal dalam pelaksanaan pembelajaran siswa di tuntut untuk aktif dalam menggali infomasi dan saling berargumentasi dalam diskusi kelas dan kelompok sehingga pembelajaran tidak berpusat pada guru sesuai dengan tuntutan kurikulum. Tetapi berdasarkan hasil wawancara tak terstruktur dengan siswa dijelaskan bahwa siswa merasa bosan dengan metode mengajar guru yang rata-rata menggunakan metode ceramah sehingga siswa tidak tertarik dengan proses pembelajaran yang berlangsung. Hal inilah yang mempengaruhi rendahnya motivasi belajar siswa dan berimbas pada rendahnya hasil belajar siswa. Rendahnya hasil belajar siswa ini tidak terlepas dari kegiatan perencanaan dan pelaksanaan pembelajaran guru dikelas, Guru lebih cenderung menggunakan metode ceramah karena dianggap fleksibel dengan keterbatasan waktu, situasi dan kondisi dan materi pembelajaran sehingga banyak guru yang memilihnya dengan pertimbangan mengejar materi sesuai dengan target kurikulum.

Berdasarkan akar permasalahan yang terjadi di lapangan maka perlu solusi yang tepat untuk mengatasinya dengan melakukan pengembangan Lembar Kerja Siswa (LKS) yang sesuai dengan kebutuhan siswa dikelas sehingga dapat menunjang guru dan siswa dalam kegiatan belajar mengajar, khususnya pada materi biologi yang bertujuan mempermudah siswa dalam 
meningkatkan hasil belajar siswa. Salah satu cara yang bisa diterapkan adalah dengan mengembangkan Lembar Kerja Siswa (LKS) model kooperatif yang mampu meningkatkan motivasi belajar siswa sehingga siswa lebih aktif dan dapat bereksplorasi dalam kegiatan pembelajaran. Salah satu model pembelajaran yang bisa diterapkan adalah model pembelajaran Discovery Learning. Menurut Hosnan .M, (2014) bahwa discovery learning adalah suatu model untuk mengembangkan cara belajar aktif dengan menemukan sendiri, menyelidiki sendiri, maka hasil yang diperoleh akan setia dan tahan lama dalam ingatan. Melalui belajar penemuan, siswa juga bisa belajar berpikir analisis dan mencoba memecahkan sendiri masalah yang dihadapi. Wilcox (dalam Hosnan. M, 2014) menyatakan bahwa dalam pembelajaran dengan penemuan, siswa didorong untuk belajar sebagian besar melalui keterlibatan aktif mereka sendiri dengan konsep-konsep dan prinsip-prinsip dan guru mendorong siswa untuk memiliki pengalaman dan melakukan percobaan yang memungkinkan mereka menemukan prinsip-prinsip untuk diri mereka sendiri.

\section{KESIMPULAN DAN SARAN}

\subsection{Kesimpulan}

Kesimpulan dari penelitian ini adalah permasalahan guru terjadi karena (1) rendahnya tingkat pemahaman guru mengenai Lembar Kerja Siswa (LKS) guru membutuhkan bimbingan , referensi , buku acuan guru dan sarana yang mendukung, (2) kegiatan pelaksanaan guru terkait Lembar Kerja Siswa (LKS) pada proses pembelajaran yang belum optimal (3) perlu adanya upaya untuk mengatasi permasalahan guru dengan mengembangkan Lembar Kerja Siswa (LKS) dengan model Discovery Learning (4) rendahnya hasil belajar siswa yang terjadi karena kurangnya motivasi dan keaktifan siswa dalam pembelajaran, dan (5) perlu adanya inovasi dalam pengembangan Lembar Kerja Siswa (LKS) Discovery learning sehingga siswa lebih termotivasi untuk meningkatkan hasil belajar kognitif siswa.

\subsection{Saran}

Berdasarkan simpulan diatas, maka di sarankan (1)pengembangan Lembar Kerja Siswa berbasis model Discovery Learning untuk meningkatkan hasil belajar siswa di SMA (2) sebaiknya guru menggunakan model pembelajaran Discovery Learning pada materi biologi yang menekankan penguasaan konsep yang melatih siswa untuk berpikir kritis dan kreatif (3) guru sebaiknya berlatih untuk merencanakan dan mengembangkan Lembar Kerja Siswa (LKS) sendiri yang disesuaikan dengan kebutuhan siswa sehingga mengerti Lembar Kerja Siswa (LKS) yang di miliki dan dilaksanakan dalam kegiatan pelaksanaan pembelajaran 


\section{DAFTAR RUJUKAN}

Asmara, J. (2016). Analisis permasalahan guru terkait pengembangan perangkat pembelajaran berbasis model think, talk, write (TTW) danpermasalahan siswa terkait ketrampilan bertanya dalam pembelajaran ipa biologi. Jurnal Pendidikan: Teori, Penelitian, dan Pengembangan, 1(10).

Dewi. R, Budiarti. R.S, dan Aina. M. (2017). Pengembangan lembar kegiatan peserta didik (LKPD) bermuatan pendidikan karakter dengan model pembelajaran guided inquiry pada materi bakteri bagi siswa kelas x sekolah menengah atas. Jurnal BIODIK, 3 (1), 17-26.

Hosnan, M. (2014). Pendekatan saintifik dan kontekstual dalam pembelajaran abad 21. Bogor: Ghalia Indonesia.

Kementerian Pendidikan dan Kebudayaan. (2014). Peraturan menteri pendidikan dankebudayaan republik indonesia nomor 103 tahun 2014 tentang Kurikulum 2013 Sekolah Menengah Atas/Madrasah Aliyah.

Momo. Idris . (2008). Strategi dan metode pengajaran. Yogyakarta Ar-ruzz Media.

Nuraini, N , (2016). Analisis permasalahan guru terkait perangkat pembelajaran berbasis mode inquiri dan permasalahan siswa terkait kemampuan pemecahan masalah dalam pembelajaran biologi di SMA. Jurnal Pendidikan: Teori, Penelitian, dan Pengembangan, I (10).

Sadikin, A. (2016). Penerapan asesmen berbasis portofolio dan jurnal belajar untuk meningkatkan kemampuan metakognitif dan motivasi belajar mahasiswa pada mata kuliah perencanaan pengajaran biologi. Jurnal Biodik 2 (2), 50-61.

Sadikin, A. (2017). Pengaruh penerapan strategi pembelajaran rotating trio exchange terhadap hasil belajar mata kuliah dasar-dasar dan proses pembelajaran biologi. Jurnal Biodik, 3 (2), 74-82.

Silberman, Malvin L, 2009. Actif Learning: 101 Strategi Pembelajaran Aktif. Yogyakarta: Pustaka Madani.

Sofian, A. (2013). Pengembangan dan model pelajaran dalam kurikulum 2013. Surabaya: PT. Prestasi Pustakakarya.

Trianto, (2007). Model-model pembelajaran iinovatif berorientasi kontruktivistik. Jakarta: Prestasi Pustaka. 